\title{
Morpho-Physiological Responses of Pisum sativum L. to Different Light-Emitting Diode (LED) Light Spectra in Combination with Biochar Amendment
}

\author{
Antonella Polzella ${ }^{1}$, Mattia Terzaghi ${ }^{2}{ }^{\circledR}$, Dalila Trupiano ${ }^{1}$, Silvia Baronti $^{3}$, \\ Gabriella Stefania Scippa ${ }^{1}$, Donato Chiatante ${ }^{4}$ (D) and Antonio Montagnoli ${ }^{4, *}$ \\ 1 Department of Biosciences and Territory, University of Molise, 86090 Pesche, IS, Italy; \\ antonella.polzella@libero.it (A.P.); dalila.trupiano@unimol.it (D.T.); scippa@unimol.it (G.S.S.) \\ 2 Department of Chemistry and Biology 'A. Zambelli', University of Salerno, 84084 Fisciano, Salerno, Italy; \\ mterzaghi@unisa.it \\ 3 Institute of Bioeconomy, National Research Council (IBE-CNR), 50145 Firenze, FI, Italy; \\ silvia.baronti@ibe.cnr.it \\ 4 Department of Biotechnology and Life Science, University of Insubria, 21100 Varese, VA, Italy; \\ donato.chiatante@uninsubria.it \\ * Correspondence: antonio.montagnoli@uninsubria.it; Tel.: +39-0332-217654
}

Received: 27 January 2020; Accepted: 11 March 2020; Published: 14 March 2020

\begin{abstract}
Light quality and nutrient availability are the primary factors that influence plant growth and development. In a research context of improving indoor plant cultivation while lowering environmental impact practices, we investigated the effect of different light spectra, three provided by light-emitting diodes (LEDs), and one by a fluorescent lamp, on the morpho-physiology of Pisum sativum L. seedlings grown in the presence/absence of biochar. We found that all morpho-physiological traits are sensitive to changes in the red-to-far-red light (R:FR) ratio related to the light spectra used. In particular, seedlings that were grown with a LED type characterized by the lowest R:FR ratio $(\sim 2.7$; AP67), showed good plant development, both above- and belowground, especially when biochar was present. Biochar alone did not affect the physiological traits, which were influenced by the interplay with lighting type. AP67 LED type had a negative impact only on leaf fluorescence emission in light conditions, which was further exacerbated by the addition of biochar to the growing media. However, we found that the combination of biochar with a specific optimal light spectrum may have a synergetic effect enhancing pea seedling physiological performances and fruit yield and fostering desired traits. This is a promising strategy for indoor plant production while respecting the environment.
\end{abstract}

Keywords: electrical lighting sources; biochar amendment; chlorophyll fluorescence; stomatal conductance; pea seedlings

\section{Introduction}

In the near future, it will be crucial to find new methods and technologies for indoor plant production with a low global environmental impact. Selection of optimal plant production systems, depending on their purpose, is increasingly needed to maintain the overall sustainability of society under changing climate and social conditions [1]. Among the many requirements for plant growth and development, light plays a key role in different processes, such as photosynthesis, plant defense, and phototropism [2]. To provide the best fitness, plants developed morpho-physiological strategies to use the available light conditions. Indeed, thanks to photoreceptors, such as phytochromes, cryptochromes, and phototropins, plants can use light of different quality, quantity, and direction [3]. Light sources such as fluorescent, metal halide, high-pressure sodium (HPS), and incandescent lamps are conventionally used for cultivating plants indoors [4,5]. Different types of electrical light sources can 
modify photosynthetic photon flux (PPF) levels [6-9] through variations in light quality and quantity. Changes in light quality trigger several morphological, physiological, biochemical, and molecular variations. Indeed, plants respond through specific photomorphogenic and physiological processes, at both the micro and macro level [10], leading to a wide range of modifications, such as improvement of antioxidant activity in pea [11], growth in tomato [12], and metabolism in mint, basil, lentil, primula, and marigold [9]. Similarly, higher growth rates due to enhanced photosynthetic and transpiration activities have been observed in cucumber [13]. Moreover, light affects root growth in grape plants and in seedlings of different tree species [14,15]. In addition, light modifies the transition to flowering delaying or inhibiting the process in Indian mustard and basil [16] and promotes the suppression of anthocyanin content in lettuce [17]. The effect of electrical light sources on plant growth depends on the properties of the light type used. The most efficient photosynthetic yield occurs in two distinct broad peaks in the blue $(400-500 \mathrm{~nm})$ and in the red $(600-700 \mathrm{~nm})$ ranges [18]. Photons in the 500-600 nm range have low photosynthetic efficiency, while photons in the far-red (FR, 700-800 nm) range are important for shoot elongation in woody plants which is modulated by the ratio of red-to-far-red light (R:FR) [19,20].

Although conventional light sources, especially HPS, are the most commonly used lighting systems to provide the necessary photosynthetic photon fluence for plant productivity, their emissions, both spectrally and energetically, are usually different from those emitted by sunlight and far from the optimal values required for photosynthesis in specific phases of plant growth [21,22]. Light-emitting diode (LED) light has the highest photosynthetically active radiation (PAR) efficiency $(\sim 90 \%)$ characterized by a monochromatic spectral specificity with possible peak emission wavelengths from $\sim 250$ (UV) to $\sim 1000 \mathrm{~nm}$ (infrared). Moreover, LED technology mimics sunlight by modulating light spectrum and direction, being thus compatible with the photosynthesis and light-signaling requirements of plants. In terms of economics and sustainability, not surprisingly, solid-state lighting using LED technology has become a major source for greenhouse lighting systems in the last decades due to a series of advantages, such as: longer lifetime (about 100,000 h), smaller volume and weight, solid-state construction, lower heat emission, and higher energy-conversion efficiency [23,24]. Additionally, specific wavelengths within a narrow spectral range can be set with the aim of precisely tuning the spectral quality and light intensity $[5,22]$. In recent years, the use of LEDs as a radiation source for plants has attracted considerable interest because of its vast potential both for developmental studies and commercial applications $[25,26]$. Thus, the selection of an optimal light spectrum is an essential task in closed plant production systems [27].

For closed plant production, it is crucial to use substrate with high nutrient availability. Biochar is natural charcoal obtained by controlled pyrolysis of organic materials (e.g., agricultural and forest residuals). The process occurs at a very high temperature range $\left(600-900^{\circ} \mathrm{C}\right)$ in an oxygen-deficient environment [28]. Biochar is considered as a novel and practical approach to bio-waste treatment and pollution remediation $[29,30]$. Depending on the process parameters, such as primary temperature and feedstock type, biochar shows different physical and structural characteristics [31]. However, the most common physical aspects are a highly porous structure and a large surface area [32]. For many years now, several studies have assessed the potential value of biochar to improve soil structure and fertility as well as plant growth [33-35]. In particular, biochar was shown to increase soil carbon and water content as well as macroaggregation, electrical conductivity (EC), total nitrates/nitrites, ammonia and nitrogen [33,36], extractable phosphorus and cation exchange capacity (CEC) [37]. Most research on biochar has focused on its effects on yield in major crops [38]. Indeed, it has been demonstrated that biochar application increases the yield of maize [39], bean (Phaseolus vulgaris) [40] and rice grain (Oryza sativa) [41,42]. A recent review highlighted how biochar application, by improving soil environments, in turn, significantly promotes root growth and morphology, mainly by increasing root length, the number of root tips, and root diameter [43]. Few studies have examined the effects of biochar on specific traits such as shoot or root morphology [44,45]. Understanding how specific above and belowground traits are impacted by biochar addition will lead to improved uses for biochar. 
Container substrates are often soilless, primarily composed of peat moss, vermiculite, perlite, bark, and compost [9]. The high cost of this substrate $[9,16]$ has led to the search for alternative container substrate components, such as biochar $[4,8,9,16]$. At the same time, the use of biochar can be considered as a means to mitigate greenhouse gas (GHG) emissions by enhancing important soil functions such as carbon sequestration and nitrogen retention thereby counteracting current global climate changes [46]. For these reasons, biochar is considered a good technological product for future sustainable plant production [47,48]. Unfortunately, the effects of biochar amendment on plant production, including cultivation of crops and forest restoration activities [49], are strongly influenced by soil type, quantity of biochar used, local conditions and/or plant species. Thus, to be able to give specific indications for future commercial use of biochar, there is an urgent need to further investigate the effects of biochar amendment on plant functional traits.

Global demand for agricultural crops is connected to a strong environmental impact mainly due to habitat fragmentation and land clearing, as well as fertilization uses that pollute both water and terrestrial ecosystems [50]. The agricultural activity necessary to meet the need of doubling crop production forecasted for the 2050s will implicate a major impact on the environment $[50,51]$. Therefore, in the near future it will be crucial to find new methods and technologies to achieve greater yields with lower global environmental impacts. The use of an optimal light source together with a natural inexpensive amendment product could help boost global food production as well as reduce its environmental impact through favoring small-scale farmers and shortening the food value chains [52]. Although the effects of different light spectra and biochar on plant performance have been studied separately, little is known about the interplay between them. The application of an optimal electrical lighting spectrum combined with biochar application could boost indoor plant production systems and reduce energy consumption for both electrical lighting and substrate production.

In the present study, the response of the fast-growing model plant Pisum sativum L. to different light spectra was investigated in combination with biochar amendment. We wanted to test the hypothesis that biochar application could be used efficiently as a component of the soil-less container substrate enhancing plant performance independently of the light spectra applied. To accomplish this, several morphological traits and physiological characteristics related to the photosynthesis machinery were measured in pea seedlings grown with or without biochar supplement under three different LED spectra and one fluorescent light spectrum.

\section{Materials and Methods}

\subsection{Plant Material and Experimental Setup}

Seeds of Pisum sativum L. (medium-late variety, medium-height plant; long, dark green pod with 8-9 seeds; large, wrinkled seed with dark green integument, by "Sementi Dotto") were obtained from a commercial nursery (Varese-Italy). Pea seeds were sown, one each, in $2 \mathrm{~L}$ sliced off inverted cone pots (h $15 \mathrm{~cm}$, lower $\varnothing 11 \mathrm{~cm}$, and upper $\varnothing 16 \mathrm{~cm}$ ), filled with commercial soil-less substrate characterized by different proportions of composition in the case of biochar-treated (1:2:1:1 mixture of peat, silica sand, bark humus, and biochar) and control (1:2:1 mixture of peat, silica sand, and bark humus). Pots were then placed in a growth chamber. Six biochar-treated plants and 6 non-treated plants were grown under each light spectrum resulting in a total of 48 plants. From the 27th day after sowing, when the leaves of $P$. sativum were fully expanded, chlorophyll fluorescence emission and stomatal conductance were measured at 4 days intervals until the 43 rd day after sowing. Seedlings were destructively sampled at 49 days after sowing for the analysis of morphological traits. All potted seedlings were watered to saturation with $400 \mathrm{~mL}$ tap water every two days. No fertilizer was added.

\subsection{Growth Room Characteristics}

Plants were kept in a single 4-m wide, 3-m deep, and 2.2-m high growth room at the University of Insubria, Varese (Italy). The room was subdivided into four sections with reflective white panels. Each 
section was illuminated with fluorescent light (FLUORA T8 (OSRAM); LEDVANCE GmbH; Garching, Germany) or one of three different commercially available LED light spectra developed specifically for horticultural purposes and coded as follow (Valoya Oy; Helsinki, Finland): NS1, AP67-3L, and AP67 (Table 1; spectrum composition and R:FR ratio were provided by the manufacturing company). Seedlings were grown under long day conditions ( $16 \mathrm{~h}$ light $/ 8 \mathrm{~h}$ dark cycle) with lights turning on at 10 a.m. Each section had a steel table with $50-\mathrm{mm}$ high edges. Light intensity yielded approximately 250-300 $\mu \mathrm{mol} \mathrm{m}^{-2} \mathrm{~s}^{-1}$ (light meter sensor-HD2302.0-Delta Ohm; Caselle di Selvazzano, Italy) at pot height. The plants were grown under $22 / 17^{\circ} \mathrm{C}$ day/night temperature with air humidity maintained at $60 \%-70 \%$.

Table 1. Spectral distribution and red:far-red ratio of three LED light sources and fluorescent light.

\begin{tabular}{|c|c|c|c|c|c|c|}
\hline \multirow{2}{*}{\multicolumn{2}{|c|}{ Light Source }} & \multicolumn{4}{|c|}{ Continuous Spectrum Wave Length (nm) } & \multirow{2}{*}{ R:FR } \\
\hline & & $400-500$ & $500-600$ & $600-700$ & $700-800$ & \\
\hline \multirow{3}{*}{ LED } & NS1 & 20.2 & 38.9 & 35.7 & 5.2 & 8.2 \\
\hline & AP67-3L & 11.9 & 19.3 & 60.5 & 8.3 & 5.6 \\
\hline & AP67 & 13.8 & 15.1 & 53.0 & 18.1 & 2.7 \\
\hline Fluorescent & Fluora T8 & 34.8 & 24.1 & 36.7 & 4.4 & 5.7 \\
\hline
\end{tabular}

\subsection{Biochar Characterization}

Biochar used in this study was produced by Romagna Carbone s.n.c. (Italy) from orchard pruning biomass through a slow pyrolysis process with an average residence time of $3 \mathrm{~h}$ at a value of temperature in the middle of the production range $\left(500^{\circ} \mathrm{C}\right)$ in a kiln of $2.2 \mathrm{~m}$ in diameter and holding around 2 tons of feedstock. The $\mathrm{pH}$ was measured by potentiometry ( $\mathrm{pH}$ meter Eutech Instruments pH 700, 2013) according to International Biochar Initiative (IBI) Biochar standards (2014). The electrical conductivity $(\mathrm{EC})$ value was obtained by the direct instrumental determination in 1:20 soil:water $(w / v)$ extracts, according to IBI standards (2014). Cation exchange capacity (CEC) was assessed according to Mehlich [53] using $\mathrm{BaCl}_{2}$. Moisture content was calculated according to the Black method [54] as the difference in sample mass before and after oven drying at $105^{\circ} \mathrm{C}$ to constant mass. In the present work, carbon stability was defined as the molar ratio of hydrogen to organic carbon (maximum 0.7 ) according to IBI standards (2014). Total nitrogen $\left(\mathrm{N}_{\text {tot }}\right)$, total carbon $\left(\mathrm{C}_{\text {tot }}\right)$, organic carbon $\left(\mathrm{C}_{\mathrm{org}}\right)$, and hydrogen $(\mathrm{H})$ contents were determined by dry combustion [55] using a CHN elemental analyzer (Carlo Erba Instruments, Mod 1500, series 2). In the case of $C_{\text {org }}$, combustion was carried out after the complete removal of inorganic $\mathrm{C}$ with acid. Available nitrogen $\left(\mathrm{N}_{\mathrm{av}}\right)$ was determined by a modified Kjeldahl procedure using Devarda's alloy [56] as reducing agent to convert $\left(\mathrm{NO}_{3}\right)$ and $\left(\mathrm{NO}_{2}\right)$ into $\left(\mathrm{NH}_{4}\right)^{+}$and subsequent Kjeldahl digestion. Total phosphorus $\left(\mathrm{P}_{\text {tot }}\right)$ content was determined by spectrophotometry (UV-1601 Shimadzu) according to the test method described by Bowman [57]. Available phosphorus $\left(\mathrm{P}_{\mathrm{av}}\right)$ was extracted by a $\mathrm{NaHCO}_{3}$ solution at $\mathrm{pH} 8.5$ and evaluated by spectrophotometry according to Olsen [58]. The alkalinity of samples with a $\mathrm{pH}$ value greater than 7.0 was determined by titrimetry, according to Higginson and Rayment [59]. The biochar tested was found to meet the European Biochar Certificate (EBC, 2012) and IBI-Standard (2014) requirements regarding $C_{\text {tot }}$ and $C_{\text {org }}$ content, respectively. Its $\mathrm{C}: \mathrm{H}$ value was close to 0.7 ensuring good stability of the organic carbon. Conductivity values indicated that the biochar used has a high salt content. Moreover, available phosphorus and nitrogen represented $17.7 \%$ and $0.3 \%$ of the total phosphorus and nitrogen, respectively (Table 2).

\subsection{Substrate Characterization}

To assess chemical and physical properties of the substrate and the effects of biochar on these characteristics, four substrate samples were collected before and after biochar application and characterized for CEC, $\mathrm{P}_{\text {tot }}$ and $\mathrm{P}_{\mathrm{av}}, \mathrm{N}_{\text {tot }}$ and $\mathrm{N}_{\mathrm{av}}$, and $\mathrm{C}_{\text {tot }}$ content as described in the previous 
paragraph. The $\mathrm{pH}$ was determined by potentiometry ( $\mathrm{pH}$ meter Eutech Instruments $\mathrm{pH} 700,2013$ ) according to Conyers and Davey [60]. EC was measured by direct instrumental determination according to Rhoades [61]. The different forms of available mineral nitrogen were determined by ion-selective electrodes [62] on substrate samples dissolved in deionized water.

Table 2. Biochar chemical-physical characteristics. Each value represents the mean $(n=8) \pm 1$ SE.

\begin{tabular}{ccc}
\hline Parameter & Unit & Value \\
\hline $\mathrm{pH}$ & - & $9.7 \pm 0.1$ \\
$\mathrm{EC}$ & $\mathrm{dS} \mathrm{m}^{-1}$ & $7.5 \pm 0.4$ \\
$\mathrm{CEC}$ & $\mathrm{Cmol} \mathrm{kg}^{-1}$ & $21.3 \pm 0.3$ \\
$\mathrm{~N}_{\text {tot }}$ & $\mathrm{g} \mathrm{kg}^{-1}$ & $9.1 \pm 0.2$ \\
$\mathrm{~N}_{\mathrm{av}}$ & $\mathrm{mg} \mathrm{kg}^{-1}$ & $30 \pm 0.4$ \\
$\mathrm{P}_{\text {tot }}$ & $\mathrm{mg} \mathrm{kg}^{-1}$ & $1221.9 \pm 21.3$ \\
$\mathrm{P}_{\mathrm{av}}$ & $\mathrm{mg} \mathrm{kg}^{-1}$ & $217 \pm 3.0$ \\
$\mathrm{C}_{\text {tot }}$ & $\mathrm{g} \mathrm{kg}^{-1}$ & $778.1 \pm 0.1$ \\
$\mathrm{C}_{\text {org }}$ & $\mathrm{g} \mathrm{kg}^{-1}$ & $705.6 \pm 0.1$ \\
$\mathrm{H}$ & $\mathrm{g} \mathrm{kg}^{-1}$ & $45.3 \pm 0.2$ \\
$\mathrm{H} / \mathrm{C}_{\text {org }}$ & - & 0.76 \\
\hline Electrical Conductivity; CEC $=$ Cation Exchange Capacity.
\end{tabular}

\subsection{Morphological Measurements}

We measured stem length (SL; $\mathrm{cm}$ ) by image acquisition of dissected stems and branches using a portable scanner (EPSON Perfection V600). Images were then analyzed by Image J software. Leaf area was measured by scanning the leaves and, subsequently, analyzing the images by WinRhizo software (Pro V. 2007d; Regent Instruments Inc.; Ville de Québec, QC, Canada); leaf area was summed for each seedling to obtain total leaf area (TLA; $\mathrm{cm}^{2}$ ). After gently removing each seedling from the medium, roots were rinsed repeatedly with running tap water and scanned ( $400 \mathrm{dpi})$ with a calibrated flatbed scanner coupled to a lighting system for image acquisition (Expression 10,000 XL; Epson America Inc.; Long Beach, CA, USA). Total fine root length (FRL; $\mathrm{cm}$ ) was obtained measuring only lateral roots by WinRhizo excluding the taproot. Afterward, fresh biomass (g) of leaves (LFM), fruit (FFM), and fine roots (FRFM) was obtained by weighing. Afterward, the plant tissues were oven drying for $52 \mathrm{~h}$ at $75^{\circ} \mathrm{C}$ and weighed again to obtain the dry mass of leaves (LDM), fruit (FDM), and fine roots (FRDM).

\subsection{Physiological Measurements}

Chlorophyll fluorescence was measured with a portable pulse-modulated fluorometer (OS1-FL, Opti-sciences, Inc., USA) on the oldest fully expanded leaf randomly selected from each seedling. Measurements were repeated five times for each plant every four days starting from the 27th day after sowing. The maximum quantum efficiency of Photosystem II (PSII) photochemistry for chlorophyll fluorescence in dark-adapted conditions $\left[\left(\mathrm{F}_{\mathrm{v}} / \mathrm{F}_{\mathrm{m}}\right)=\left(\mathrm{F}_{\mathrm{m}}-\mathrm{F}_{0}\right) \mathrm{F}_{\mathrm{m}-1}\right]\left(\mathrm{F}_{0}\right.$ indicating the minimum value for chlorophyll fluorescence obtained with the 'measuring light' switched on; $F_{m}$ indicating the maximal possible value for fluorescence obtained with the application of a saturating pulse to a dark-adapted leaf; $F_{v}$ indicating the variable fluorescence as the difference between $F_{0}$ and $F_{m}$ ) was measured in the mid-morning when lights were still off or right after their turning on (10-11 a.m.). In the latter case, leaves were pre-darkened with a leaf clip for $45 \mathrm{~min}$ to ensure complete relaxation of all reaction centers. The maximum efficiency of PSII photochemistry in the light $\left[\Phi_{\mathrm{PSII}}=\left(\mathrm{F}_{\mathrm{ms}}-\mathrm{F}_{\mathrm{s}}\right) \mathrm{F}_{\mathrm{ms}-1}\right]\left(\mathrm{F}_{\mathrm{s}}\right.$ indicating the steady-state level of fluorescence in the light; $F_{m s}$ indicating the value of maximal fluorescence in the light-adapted obtained by the application of a saturating pulse under actinic illumination) was measured in the afternoon (3-4 PM). Finally, non-photochemical quenching $\left[N P Q=\left(F_{m}-F_{m s}\right)\right.$ $\mathrm{F}_{\mathrm{ms}-1}$ ] was calculated [63]. Stomatal conductance, as water vapor $\left(\mathrm{g}_{\mathrm{s}} ; \mathrm{mmol} \mathrm{m}^{-2} \mathrm{~s}^{-1}\right)$, was measured 
using a steady state porometer (PMR 3, PPSystem, MA, USA) between 2 and 3 p.m. When seedlings were harvested for destructive measurements, $2.5 \mathrm{~g}$ of leaf tissue was sampled from untreated and biochar-treated seedlings for each of the light spectra and then stored at $-80{ }^{\circ} \mathrm{C}$. Pigment measurement was performed according to Arnon [64]. In particular, chlorophylls (Chl $a$; Chl $b$; Chl $a+b)$ and carotenoids (Car) were extracted from $0.25 \mathrm{~g}$ leaf tissue using $80 \%$ acetone as a solvent. The pigment concentrations were determined by spectrophotometer (BioRad) using the following Equations (1)-(4):

$$
\begin{gathered}
\text { Chl } a=12.70_{A 663}-2.69_{A 645} \\
\text { Chl } b=22.90_{A 645}-4.68_{A 663} \\
\text { Chl } a+b=20.20_{A 645}+8.02_{A 663} \\
\text { Car }=\left(1000_{A 470}-1.82_{[\mathrm{Chl} a]}-85.02_{[\mathrm{Chl} b]}\right) / 198
\end{gathered}
$$

where $A$ is absorbance in $1.00 \mathrm{~cm}$ cuvettes and $\mathrm{Chl}$ is expressed as $\mu \mathrm{g} \mathrm{mL}{ }^{-1}$.

\subsection{Statistical Analysis}

To evaluate significant differences between values, three comparisons for each morphological and physiological measured parameter were performed: (a) untreated versus biochar-treated plants grown under the same light conditions, (b) untreated plants grown under different light conditions, (c) biochar-treated plants grown under different light conditions. Morphological data were analyzed using a two-tailed $t$-test. Physiological data were analyzed by a two-way ANOVA with biochar treatment and lighting type as fixed factors and with time as a random factor (due to repeated measures). The analysis of variance was performed on original data or data transformed to meet homoscedastic distribution. The post hoc LSD-tests $(p<0.05)$ were performed to test differences among lighting type for both untreated and biochar-treated plants. A two-tailed t-test was applied to test differences between untreated and biochar-treated plants for the same lighting type. All tests were performed with a 5\% rejection level. Statistical analysis was performed with SPSS 17.0 (SPSS Inc., Chicago, IL, USA).

\section{Results}

\subsection{Substrate Characteristics}

Substrate chemical analysis showed that biochar addition resulted in an increase of $\mathrm{N}_{\mathrm{av}}$ and $\mathrm{C}_{\text {tot }}$ values, while $\mathrm{pH}, \mathrm{EC}, \mathrm{CEC}, \mathrm{N}_{\text {tot }}, \mathrm{P}_{\text {tot, }}$ and $\mathrm{P}_{\mathrm{av}}$ remained unchanged (Table 3 ).

Table 3. Chemical and physical analysis performed on soil-less substrate alone and with the addition of biochar. Each value represents the mean of 8 samples \pm SE. Different letters indicate statistically significant differences between data for the same parameter at $p<0.05$.

\begin{tabular}{cccc}
\hline Parameter & Unit & Substrate & Substrate + Biochar \\
\hline $\mathrm{pH}$ & - & $6.6 \pm 0.07 \mathrm{a}$ & $6.69 \pm 0.07 \mathrm{a}$ \\
$\mathrm{EC}$ & $\mathrm{dS} \mathrm{m}^{-1}$ & $0.9 \pm 0.3 \mathrm{a}$ & $0.9 \pm 0.3 \mathrm{a}$ \\
$\mathrm{CEC}$ & $\mathrm{Cmol} \mathrm{kg}^{-1}$ & $18 \pm 0.87 \mathrm{a}$ & $19 \pm 0.92 \mathrm{a}$ \\
$\mathrm{N}_{\text {tot }}$ & $\mathrm{g} \mathrm{kg}^{-1}$ & $13 \pm 1.23 \mathrm{a}$ & $15 \pm 1.42 \mathrm{a}$ \\
$\mathrm{N}_{\mathrm{av}}$ & $\mathrm{mg} \mathrm{kg}^{-1}$ & $120 \pm 4.8 \mathrm{a}$ & $140 \pm 5.6 \mathrm{~b}$ \\
$\mathrm{P}_{\text {tot }}$ & $\mathrm{mg} \mathrm{kg}^{-1}$ & $456.6 \pm 16.7 \mathrm{a}$ & $484.1 \pm 18 \mathrm{a}$ \\
$\mathrm{P}_{\mathrm{av}}$ & $\mathrm{mg} \mathrm{kg}^{-1}$ & $40.41 \pm 2.22 \mathrm{a}$ & $42.44 \pm 2.33 \mathrm{a}$ \\
$\mathrm{C}_{\text {tot }}$ & $\mathrm{g} \mathrm{kg}^{-1}$ & $23 \pm 0.55 \mathrm{a}$ & $26 \pm 0.63 \mathrm{~b}$ \\
\hline
\end{tabular}

$\mathrm{EC}=$ Electrical conductivity $; \mathrm{CEC}=$ Cation Exchange Capacity. 


\subsection{Morphological Traits}

Seedlings grown in control media with NS1 LED were taller (stem length; SL) than those grown with fluorescent light, while they had the same height as AP67-3L and AP67 seedlings, which were not significantly different from each other. In biochar-amended substrate, SLs of AP67-3L and AP67 seedlings were similar to each other and greater than that of seedlings grown under fluorescent light or NS1. Biochar application increased SL in seedlings grown with AP67-3L and AP67, while a decrease was observed with NS1 (Table 4). In control media, the greatest total leaf area (TLA) was found for seedlings grown with AP67-3L and AP67, while seedlings kept under fluorescent and NS1 light had the intermediate and the lowest values, respectively. In biochar-amended medium, no significant differences in TLA were observed among different light treatments. Biochar application caused TLA to increase in NS1 seedlings and to decrease in AP67 seedlings (Table 4).

Table 4. Values of morphological traits referring to both aboveground (leaves and stem) and belowground (fine roots) compartments measured in seedlings grown in untreated or biochar-treated substrate under fluorescent or different LED light spectra.

\begin{tabular}{|c|c|c|c|c|c|c|}
\hline \multirow{3}{*}{ Parameter } & \multirow{3}{*}{ Units } & \multirow{3}{*}{$\begin{array}{c}\text { Untreated (C) } \\
\text { Biochar-Treated (B) }\end{array}$} & \multicolumn{4}{|c|}{ Light Source } \\
\hline & & & Fluorescent & & LED & \\
\hline & & & Fluora T8 & NS1 & AP67-3L & AP67 \\
\hline \multicolumn{7}{|c|}{ Aboveground } \\
\hline \multirow[t]{2}{*}{ SL } & \multirow[t]{2}{*}{$\mathrm{cm}$} & $\mathrm{C}$ & $110(7) \mathrm{b}$ & 154 (9) a & $\begin{array}{c}138(13.30) \\
\mathrm{ab}\end{array}$ & $123(9) a b$ \\
\hline & & B & 127 (12) yz & $122(6) \mathrm{z}$ & $180(5) \mathrm{x}$ & 159 (7) xy \\
\hline \multirow{2}{*}{ TLA } & \multirow{2}{*}{$\mathrm{cm}^{2}$} & $\mathrm{C}$ & $431(51) b$ & $398(52) \mathrm{c}$ & $542(12) a b$ & 587 (26) a \\
\hline & & B & $460(42) x$ & $608(63) x$ & $523(48) x$ & $457(20) x$ \\
\hline \multirow{2}{*}{ LFM } & \multirow{2}{*}{$\mathrm{g}$} & $\mathrm{C}$ & $15.60(2) b c$ & $18.1(2) \mathrm{c}$ & $21.1(1.5) \mathrm{ab}$ & $24.9(0.6) \mathrm{a}$ \\
\hline & & B & $18.80(3.1) \mathrm{x}$ & $21.9(3.6) x$ & $21.6(0.6) x$ & $18.3(2.4) x$ \\
\hline \multirow{2}{*}{ LDM } & \multirow{2}{*}{ g } & $\mathrm{C}$ & $2.12(0.3) b c$ & $2(0.2) \mathrm{c}$ & $2.9(0.3) \mathrm{ab}$ & $3.30(0.1) \mathrm{a}$ \\
\hline & & B & $2.63(0.3) x$ & $2.4(0.4) \mathrm{x}$ & $3.3(0.3) x$ & $2.9(0.5) x$ \\
\hline \multirow{2}{*}{ FFM } & \multirow{2}{*}{ g } & $\mathrm{C}$ & $2.7(0.5) b$ & $0.3(0.2) c$ & $8.6(0.2) \mathrm{a}$ & $5.4(0.6) \mathrm{b}$ \\
\hline & & B & $7.4(0.7) x$ & - & $7.5(1.3) \mathrm{x}$ & $8.8(0.5) x$ \\
\hline \multirow{2}{*}{ FDM } & \multirow{2}{*}{$\mathrm{g}$} & $\mathrm{C}$ & $0.34(0.06) \mathrm{b}$ & $0.05(0.03) \mathrm{c}$ & 1.15 (0.03) a & $0.5(0.06) b$ \\
\hline & & B & $0.91(0.15) \times$ & - & $1.09(0.2) x$ & $1.05(0.21) \times$ \\
\hline \multicolumn{7}{|c|}{ Belowground } \\
\hline \multirow{2}{*}{ FRL } & \multirow{2}{*}{$\mathrm{m}$} & $\mathrm{C}$ & $70(5) \mathrm{a}$ & $43(5) b$ & $50(7) a b$ & $53(5) b$ \\
\hline & & B & $56(3) y$ & $56(4) y$ & $42(9) \mathrm{y}$ & $84(5) x$ \\
\hline \multirow{2}{*}{ FRFM } & \multirow{2}{*}{ g } & C & $3.2(0.3)$ a & $2.5(0.2) \mathrm{b}$ & $2.4(0.1) b$ & $3.2(0.4) \mathrm{a}$ \\
\hline & & B & $4.2(0.3) x y$ & $3.4(0.5) x y$ & $3.0(0.4) x$ & $4.5(0.3) x$ \\
\hline \multirow{2}{*}{ FRDM } & \multirow{2}{*}{ g } & $\mathrm{C}$ & $0.19(0.02) \mathrm{a}$ & $0.12(0.01) b$ & $0.12(0.02) b$ & $0.17(0.03) \mathrm{ab}$ \\
\hline & & B & $0.17(0.01) x y$ & $0.16(0.02) x y$ & $0.12(0.02) \mathrm{y}$ & $0.22(0.02) x$ \\
\hline
\end{tabular}

Values show the mean (SE) of six samples. Bold values indicate statistically significant differences between untreated and biochar-treated plants with the same lighting treatment $(p<0.05)$. Letters $\mathrm{a}, \mathrm{b}$, and $\mathrm{c}$ indicate statistically significant differences among lighting types within control plants $(p<0.05)$. Letters $\mathrm{x}, \mathrm{y}$, and $\mathrm{z}$ indicate statistically significant differences among lighting types within biochar-treated plants $(p<0.05)$. SL stem length, TLA total leaf area, LFM and LDM leaf fresh and dry mass, FFM and FDM fruit fresh and dry mass, FRL total fine root length, FRFM and FRDM fine root fresh and dry mass. 
Leaf fresh mass (LFM) was highest for seedlings grown with AP67, although no statistical difference was found for values measured with AP67-3L. Fluorescent light and NS1 represented the intermediate and lowest LFM values, respectively. Finally, LFM of biochar-treated seedlings was similar among all light types, with only in the case of AP67, it being significantly lower than that found for untreated seedlings. Leaf dry mass (LDM) was greatest with AP67 and lowest with NS1. Seedlings grown with fluorescent light or AP67-3L had intermediate values although they were not significantly different from those measured for AP67 and NS1. Biochar application did not affect LDM with any of the different spectra (Table 4). Both fresh and dry fruit masses (FFM, FDM) were greatest with AP67-3L and lowest with NS1. Seedlings grown with fluorescent and AP67 light types had intermediate FFM and FDM values, which increased significantly when pots were supplemented with biochar, reaching, in the case of AP67, the highest fruit yield (Table 4). For seedlings grown in control media, fine root length (FRL) was greatest with fluorescent light and lowest with NS1 and AP67, while AP67-3L seedlings showed intermediate values. Biochar-treated seedlings had the greatest FRL value with AP67 with no significant differences among the other light sources. Biochar application significantly increased FRL only in the case of AP67 (Table 4). Both fresh (FRFM) and dry (FRDM) mass of fine roots showed the highest values for seedlings grown under fluorescent light and AP67, while lower values were found for NS1 and AP67-3L, which were similar to each other. When grown in biochar-amended medium, seedlings showed, only in the case of AP67 light type, a higher FRFM than the control seedlings. The dry mass of fine roots did not show any improvement when biochar-treated seedlings were analyzed (Table 4). Similar values were measured for all light spectra, except AP67-3L, which had the lowest value although not significantly different from fluorescent and NS1 lights.

\subsection{Physiological Traits}

The maximum quantum efficiency of PSII photochemistry in dark-adapted conditions $\left(\mathrm{F}_{\mathrm{v}} / \mathrm{F}_{\mathrm{m}}\right)$ was not significantly affected by biochar treatments (Figure 1A). This is in agreement with our statistical model, which shows the influence of lighting type alone (Table 5). In particular, the highest and the lowest values were found for plants grown with AP67 and NS1 light, respectively, while values for fluorescent and AP67-3L light were intermediate. Biochar treatment alone did not affect the quantum yield maximum efficiency of PSII photochemistry in light conditions $\left(\Phi_{\mathrm{PSII}}\right)$, while this parameter was affected by the interaction of biochar and light type as well as by the lighting type alone (Table 5). Data were similar across all light types with the exception of AP67, which showed the lowest values of $\Phi_{\text {PSII }}$ for both control and biochar treated plants (Figure 1B). Only in the case of AP67, the biochar-treated plants showed lower values than control plants (Figure 1B). Neither biochar or light treatment alone nor their combination affected non-photochemical quenching (NPQ) (Table 5). In the case of control seedlings, the highest and the lowest values were measured for the fluorescent and AP67 light types, respectively, while NS1 and AP67-3L showed intermediate values (Figure 1C). No differences were detected among the four light types in the case of biochar-treated seedlings. 

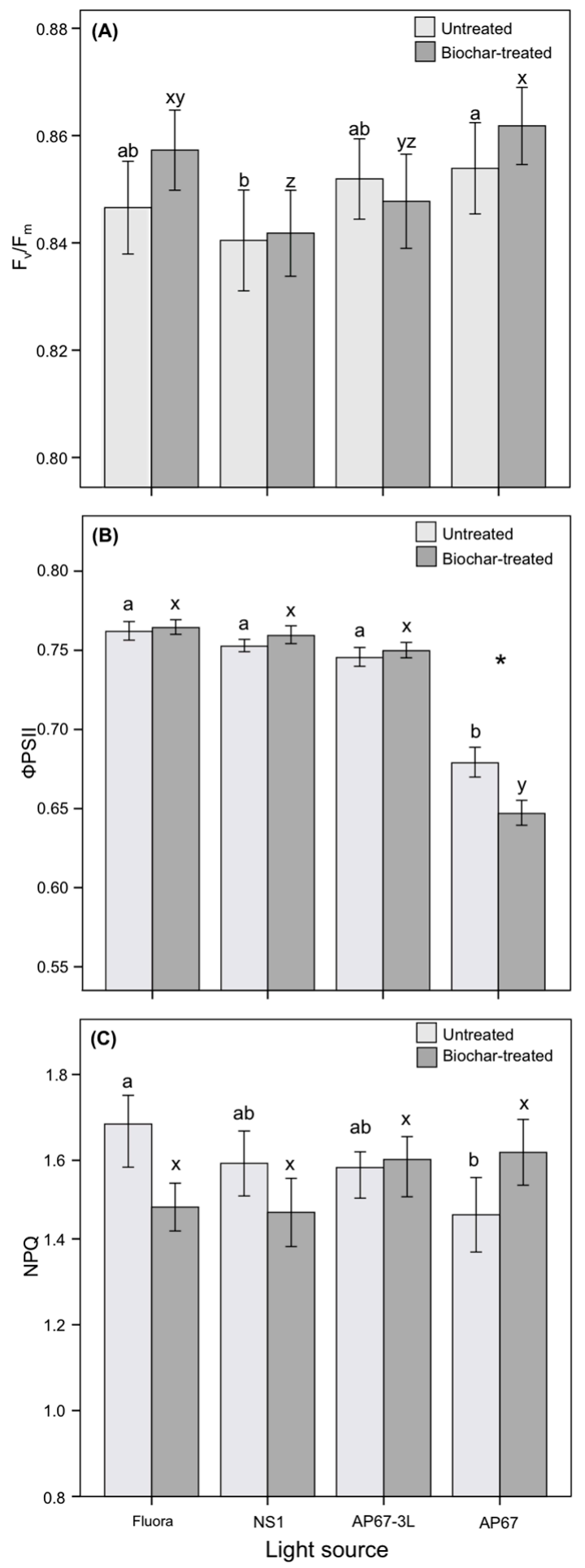

Figure 1. Data means of chlorophyll fluorescence in dark-adapted conditions (Fv/Fm), maximum efficiency of PSII photochemistry in the light-adapted conditions (ФPSII) and non-photochemical quenching (NPQ) for seedlings grown in untreated (control; light grey bars) and biochar-treated (dark grey bars) substrate with fluorescent light and three different light-emitting diode (LED) light spectra. The asterisk $\left.{ }^{*}\right)$ indicates statistically significant differences between untreated and biochar-treated plants with the same lighting treatment $(p<0.05)$. Letters $\mathrm{a}, \mathrm{b}, \mathrm{c}$ indicate statistically significant differences among lighting types in control plants $(p<0.05)$. Letters $\mathrm{x}, \mathrm{y}, \mathrm{z}$ indicate statistically significant differences among lighting types in biochar-treated plants $(p<0.05)$. 
Biochar treatment alone did not affect stomatal conductance $\left(g_{s}\right)$, while this parameter was affected by the interaction between biochar and light type as well as by light type alone (Table 5). Stomatal conductance did not differ across light types for control seedlings (Figure 2). When biochar was applied, stomatal conductance was highest with AP67 light and lowest with the fluorescent and AP67-3L light. An intermediate value was found for seedlings grown under NS1 light (Figure 2). Only in the case of fluorescent light, the application of biochar significantly reduced stomatal conductance compared to control conditions (Figure 2). Analysis of chlorophyll extraction could not detect any significant differences in $\mathrm{Chl} a, \mathrm{Chl} b, \mathrm{Chl} a+b$, and Car contents (data not shown).

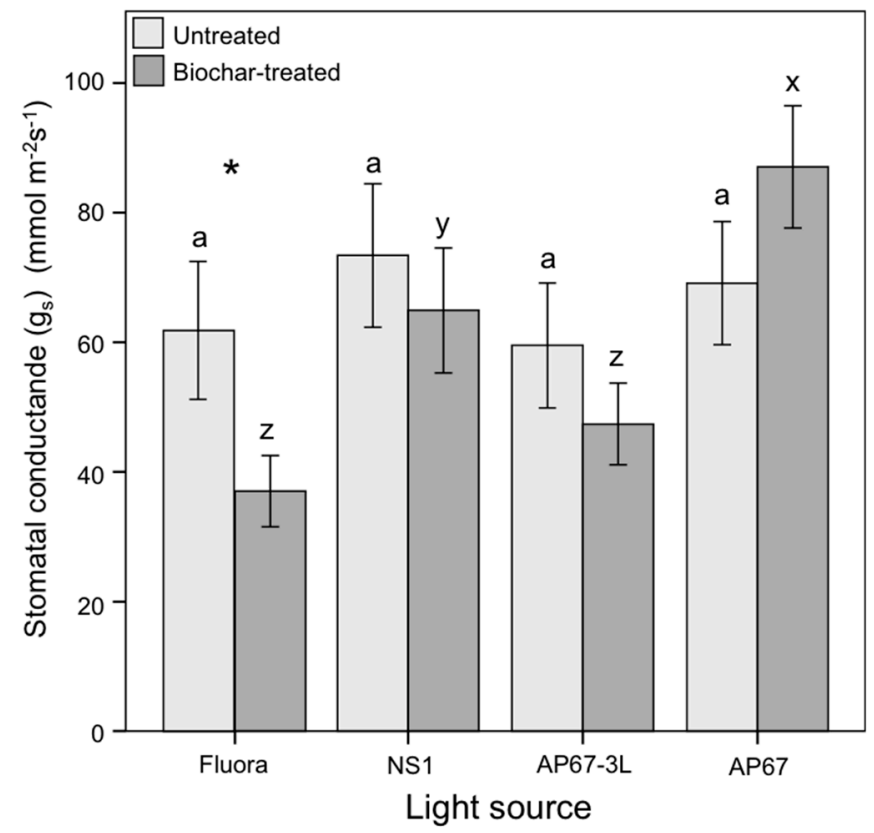

Figure 2. Stomatal conductance (gs; as water vapor) for seedlings grown in untreated (control; light grey bars) and biochar-treated (dark grey bars) substrate with fluorescent light and three different LED light spectra. The asterisk $\left(^{*}\right)$ indicates statistically significant differences between untreated and biochar-treated plants with the same lighting treatment $(p<0.05)$. Letters $\mathrm{a}, \mathrm{b}, \mathrm{c}$ indicate statistically significant differences among lighting types in untreated plants $(p<0.05)$. Letters $\mathrm{x}, \mathrm{y}, \mathrm{z}$ indicate statistically significant differences among lighting types within biochar-treated plants $(p<0.05)$.

Table 5. Split-plot design two-way ANOVA with biochar treatment and lighting type (fluorescent and three LED light spectra) as fixed factors and time as random factor on $\mathrm{F}_{\mathrm{v}} / \mathrm{F}_{\mathrm{m}}, \Phi_{\mathrm{PSI}}, \mathrm{NPQ}$ and $\mathrm{g}_{\mathrm{s}}$. Bold values indicate statistically significant differences $(p<0.05)$.

\begin{tabular}{cccccc}
\hline Fixed factors & & $\mathbf{F}_{\mathbf{v}} / \mathbf{F}_{\mathbf{m}}$ & $\mathbf{\Phi}_{\mathbf{P S I I}}$ & $\mathbf{N P Q}$ & $\mathbf{g}_{\mathbf{s}}$ \\
\hline \multirow{2}{*}{ Biochar treatment $(B)$} & $\mathrm{F}$ & 1.942 & 1.329 & 0.491 & 1.827 \\
& $p$ & 0.165 & 0.251 & 0.485 & 0.178 \\
Lighting type $(L)$ & $\mathrm{F}$ & 6.212 & 120.47 & 0.321 & 8.072 \\
& $p$ & $<\mathbf{0 . 0 0 1}$ & $<\mathbf{0 . 0 0 1}$ & 0.810 & $<\mathbf{0 . 0 0 1}$ \\
B $x L$ & $\mathrm{~F}$ & 1.587 & 4.470 & 0.156 & 3.698 \\
& $p$ & 0.194 & $\mathbf{0 . 0 0 5}$ & 0.095 & $\mathbf{0 . 0 1 3}$ \\
\hline Random factor & & & & & \\
\hline \multirow{2}{*}{ Time } & $\mathrm{F}$ & 162.53 & 4.978 & 2.941 & 44.95 \\
& $p$ & $<\mathbf{0 . 0 0 1}$ & $\mathbf{0 . 0 0 1}$ & $\mathbf{0 . 0 2 2}$ & $<\mathbf{0 . 0 0 1}$ \\
\hline
\end{tabular}

$\mathrm{F}_{\mathrm{v}} / \mathrm{F}_{\mathrm{m}}$ indicates the chlorophyll fluorescence in dark-adapted conditions; $\Phi_{\mathrm{PSII}}$ indicates the maximum efficiency of PSII photochemistry in the light; NPQ indicates the non-photochemical quenching; $g_{s}$ indicates the stomatal conductance. 


\section{Discussion}

In the present work, we assessed various morpho-physiological traits of P. sativum seedlings in response to biochar amendment under different light spectra provided by LED and fluorescent lighting systems. Seedlings showed specific responses to both the presence of biochar, as well as to different light spectra. For most of the morphological traits, and independently of the light spectra, we generally observed a positive effect on seedlings grown in the presence of biochar. This finding is in accordance with observations reported by Berihun et al. [65], who related such variations in plant morphology to the improved substrate characteristics after biochar application. Indeed, among many factors, organic matter (total carbon) and nitrogen content are most likely to have a beneficial impact on substrate quality [66]. In our study, together with a significant increase in total carbon and nitrogen availability measured in biochar-amended substrate, a higher fruit mass, both fresh and dry, was detected. These findings are in line with previous studies that highlighted an indirect promotion of fruit productivity related to biochar application $[65,67,68]$. Alternatively, Solaiman et al. [69] ascribed the enhancement in growth of bean plants by biochar application to the increase of substrate $\mathrm{pH}$ and nutrient availability. Beside substrate characteristics, although not measured in this study, these results could be attributable to the different regulation of some genes involved in leaf expansion and the flowering process in the presence of biochar [70]. Concerning the influence of light spectra, the analysis of morphological traits highlighted different responses depending on the plant sector considered. We noted a general stimulation in growth and development of the above-ground part of seedlings grown with AP67 and to a lesser extent with AP67-3L, two lighting types characterized by the lowest R:FR ratio values. Many reports studied the effect of low R:FR values on morphological traits in several plant species, reporting increased plant growth independently of the successional status (i.e., early or late) [13,71,72]. Moreover, a low R:FR ratio could be attributable to the shading by other plants, leading to a stimulation of elongation growth as a shade avoidance response and an adaptive advantage for competition [73-75]. Additionally, it was observed that biochar application reduced stem length and increased leaf area of seedlings grown with NS1, probably due to its high content of blue-green light and R:FR ratio. Our study suggests the possibility to modulate light spectra as a tool for fostering specific seedlings traits [14]. Indeed, considering fine roots, responsible for soil exploitation taking up water and nutrients [76-78], our results are in line with other studies $[43,68,79]$ showing a positive effect of biochar application on both fine root length and fresh mass, probably due to the improved water and nutrient availability. However, our data are in contrast with those reported by Amendola et al. [33], who found an increased root diameter but unchanged root length in grapevine plants in response to biochar application. Probably these differences are attributable to the fact that seedlings were grown in the presence of different light spectra. Indeed, the belowground part of the seedlings responded with a higher variability to differences in light spectra than did shoots. However, since roots are covered by soil, it remains unclear how light could influence their morphology. Many studies demonstrated a direct contribution of light signals perceived above ground in the regulation of growth and development of belowground parts through several internal light signal transduction systems from stem to roots [80]. For instance, stem and root vascular tissues can axially conduct light [81], and light can be transmitted to specific depths eliciting light-sensitive positive geotropism responses [82,83]. In our study, fluorescent light and AP67 had the strongest effect on root morphology in untreated and biochar-treated seedlings, respectively. Finally, we suggest that biochar-treated seedlings had, in general, higher root biomass than untreated ones. More interestingly, seedlings with the longest roots were those grown with AP67 light. The root-elongation effect of AP67 together with biochar application could be attributable to the spectrum composition (lowest R: FR ratio and highest red-light content) as found by other reported studies in which the same LED light types $[13,19]$ or light sources with the same spectrum characteristics were used [84,85].

Regarding physiological traits, biochar amendment alone did not significantly affect the parameters analyzed. Values observed for control seedlings did not differ from those measured for biochar-treated ones with only two exceptions discussed later on. Thus, biochar application alone does not seem 
to improve photosynthetic activity. Our findings are in contrast with a study on Malus hupehensis seedlings [86] where biochar noticeably increased the photosynthetic rate of three-months-old seedlings. This result could also be attributable to the timing of exhausting seed reserves in plant development, mainly at early developmental stages $[13,87]$. In our study, for all the considered light spectra, $\mathrm{F}_{\mathrm{v}} / \mathrm{F}_{\mathrm{m}}$ remained around and above the optimal value of $0.83[63,88,89]$, confirming that PSII efficiency was not affected by light spectra variation and biochar application. Dark-adapted values of $F_{v} / F_{m}$ reflect the potential quantum efficiency of PSII, making them sensitive indicators of plant photosynthetic performance [63]. The actual $\Phi_{\text {PSII }}$, related to the achieved PSII efficiency, was similar among all different spectra with the only exception being seedlings grown with AP67 light, which showed the lowest values of fluorescence emission in light conditions $\left(\Phi_{\mathrm{PSII}}\right)$, further reduced in the case of biochar application. According to Schansker et al. [90], a decrease in $\Phi_{\mathrm{PSII}}$ could indicate an inhibition of the redox reaction after the primary acceptor quinone $\left(Q_{A}\right)$ with a slowdown in electron transfer between $\mathrm{Q}_{\mathrm{A}}$ and the secondary acceptor $\left(\mathrm{Q}_{\mathrm{B}}\right)$. In addition, although biochar-treated seedlings grown with AP67 showed high values of $F_{v} / F_{m}$ in comparison with untreated seedlings, they did not show a positive

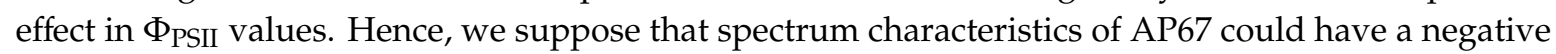
impact on the performance and activity of the photosynthetic machinery.

Lighting type alone significantly affected PSII activity and stomatal conductance. More interesting was the significant interplay between biochar and lighting type, suggesting that the simultaneous presence of biochar amendment and optimal light spectra influence photosystem II activity. Indeed, Huang et al. [91] demonstrated that N-deficiency conditions could cause a loss of photosynthetic pigments. In the present study, biochar application led to an increase in nitrogen availability and organic carbon in the substrate, which could affect photosynthetic performance. Furthermore, Viger et al. [69] in their work proved that biochar application promotes plant growth through auxin up-regulation, while Salisbury et al. [92] found a possible crosstalk between plant phytochrome photoreceptors and auxins content in promoting plant development.

NPQ is one of the consequences of the fluorescence-quenching phenomenon, during which energy is converted to heat with increased efficiency and heat dissipation occurs [63]. In our work, this parameter was not significantly influenced by light type or biochar application, either alone or in combination. Indeed, the different types of light spectra only slightly affected NPQ in control seedlings, while no effect was detected in biochar-amended ones.

Although many studies have reported a positive effect of biochar application on stomatal density and conductance $[93,94]$, in our case the addition of biochar did not change stomatal conductance. The large water retention capacity of biochar may cause a reduction in root water availability, inducing a water deficit and determining plant stomatal closure $[95,96]$. However, in our study this was not the case since water availability was high throughout the whole experiment. When stomatal conductance was analyzed in response to lighting type, and to the interplay between light and biochar, no statistically significant effect was found. It has been widely reported that specific mechanisms of several photoreceptors might promote stomatal opening and density depending on the wavelength of incident light [97]. In our case, although seedlings grown with AP67 showed the highest $g_{s}$ values when biochar was added, a strong decrease of $g_{s}$ was measured in biochar-treated seedlings grown with fluorescent light spectra. Thus, our findings support the hypothesis that stomatal opening is related to both spectrum composition and biochar presence. Indeed, Jensen et al. [98], studying the relationship between stomatal activity and stomata density, found an increase in stomata density in response to increasing ratios of blue light and a decrease in stomata density with decreasing ratios of green light. Likewise, it has been seen that green-light exposure reversibly decreases stomatal conductance in lettuce [99] leading to an unfavorable effect on the plants, including a decrease in chlorophyll content and an inhibition of stomatal opening [100]. In our case, fluorescent light, and to a lesser extent AP67-3L, are characterized by the highest percentage of green-blue light and, thus, negatively affect stomatal activity, especially when amended with biochar. 


\section{Conclusions}

The morpho-physiological traits here reported represent the first attempt to unveil plant growth mechanisms in response to modifications in light spectrum and substrate characteristics. The present work showed that biochar application to a soilless substrate has a general positive effect on aboveand belowground plant morphology. In particular, P. sativum seedlings grown with the fluorescent control or AP67 light types doubled their fruit yield. Pea seedlings showed the greatest aboveground and belowground plant development when a light spectrum with low R:FR ratio was used. This might be due to the adaptive advantage for competition as a shade avoidance response. However, when biochar was tested alone it did not improve PSII activity, but, interestingly, when combined with a specific optimal light spectrum, biochar may improve pea seedling physiological performances and change biomass organ allocation. This allows us to infer a positive synergic effect of enhanced substrate characteristics, due to biochar application, and increased plant growth and development due to the AP67 light spectrum. Thus, we demonstrated that closed plant production systems might become more efficient by selecting an optimal LED light spectrum and including biochar amendment in the horticultural production process.

Author Contributions: Conceptualization, G.S.S., D.C., and A.M.; methodology, M.T., D.T., S.B., and A.M.; software, A.P. and M.T.; validation, A.P., D.T., S.B., and A.M.; formal analysis, A.P., M.T., D.T., S.B., and A.M.; investigation, A.P., M.T., D.T., S.B., and A.M.; resources, D.C., G.S.S., and A.M.; data curation, A.P., M.T., D.T., and S.B.; writing-original draft preparation, A.P. and A.M.; writing-review and editing, A.P. and A.M.; visualization, A.P., M.T., and A.M.; supervision, D.C., G.S.S., and A.M., project administration, A.M.; funding acquisition, G.S.S. and C.D. All authors have read and agreed to the published version of the manuscript.

Funding: This work was supported by the University of Insubria [FAR 2013-2016; Research grant 'Junior' 2016-2017]; the EC FP7 [ZEPHYR, grant number 308313, 2012-2015].

Acknowledgments: We are grateful to Barbara Baesso for her valuable help with laboratory work.

Conflicts of Interest: The authors declare no conflict of interest.

\section{References}

1. Kozai, T.; Niu, G.; Takagaki, M. Plant Factory: An Indoor Vertical Farming System for Efficient Quality Food Production; Elsevier: London, UK, 2016.

2. Ballaré, C.L. Light regulation of plant defense. Annu. Rev. Plant Biol. 2014, 65, 335-363. [CrossRef]

3. Batschauer, A. Light perception in higher plants. Cell Mol. Life Sci. 1999, 55, 153-166. [CrossRef]

4. Jeong, S.W.; Park, S.; Jin, J.S.; Seo, O.N.; Kim, G.S.; Kim, Y.H.; Bae, H.; Lee, G.; Kim, S.T.; Lee, W.S.; et al. Influences of four different light-emitting diode lights on flowering and polyphenol variations in the leaves of Chrysanthemum (Chrysanthemum morifolium). J. Agric. Food Chem. 2012, 60, 9793-9800. [CrossRef]

5. Ouzounis, T.; Fretté, X.; Rosenqvist, E.; Ottosen, C.O. Spectral effects of supplementary lighting on the secondary metabolites in roses, chrysanthemums, and campanulas. J. Plant Physiol. 2014, 171, 1491-1499. [CrossRef]

6. Chen, M.; Tao, Y.; Lim, J.; Shaw, A.; Chory, J. Regulation of phytochrome B nuclear localization through light-dependent unmasking of nuclear-localization signals. Curr. Biol. 2005, 15, 637-642. [CrossRef]

7. Kopsell, D.A.; Sams, C.E.; Morrow, R.C. Interaction of light quality and fertility on biomass, shoot pigmentation and xanthophyll cycle flux in Chinese kale. J. Sci. Food Agric. 2017, 97, 911-917. [CrossRef]

8. Krizek, D.T.; Mirecki, R.M.; Bailey, W.A. Uniformity of photosynthetic photon flux and growth of 'poinsett' cucumber plants under metal halide and microwave-powered sulfur lamps. Biotronic 1998, 27, 81-92.

9. Mohammed, S.; Parisa, H.; Morteza, Z.; Amin, B.; Mehran, A.; Mohammad, S.; Benoît, S. High performance of vegetables, flowers, and medicinal plants in a red-blue LED incubator for indoor plant production. Agron. Sustain. Dev. 2014, 34, 879-886.

10. Castiglione, F.; Pappalardo, F.; Bianca, C.; Russo, G.; Motta, S. Modeling biology spanning different scales: An open challenge. BioMed Res. Int. 2014, 2014, 902545. [CrossRef]

11. Wu, M.C.; Hou, C.Y.; Jiang, C.M.; Wang, Y.T.; Wang, C.Y.; Chen, H.H.; Chang, H.M. A novel approach of LED light radiation improves the antioxidant activity of pea seedling. Food Chem. 2007, 101, 1753-1758. [CrossRef] 
12. Gómez, C.; Mitchell, C.A. Growth responses of tomato seedlings to different spectra of supplemental lighting. HortScience 2015, 50, 112-118. [CrossRef]

13. Hernández, R.; Kubota, C. Physiological responses of cucumber seedlings under different blue and red photon flux ratios using LEDs. Environ. Exp. Bot. 2016, 121, 66-74. [CrossRef]

14. Montagnoli, A.; Dumroese, R.K.; Terzaghi, M.; Pinto, J.R.; Fulgaro, N.; Scippa, G.S.; Chiatante, D. Tree seedling response to LED spectra: Implications for forest restoration. Plant Biosyst. 2018, 152, 515-523. [CrossRef]

15. Poudel, P.R.; Kataoka, I.; Mochioka, R. Effect of red- and blue-light-emitting diodes on growth and morphogenesis of grapes. Plant Cell Tissue Organ Cult. 2008, 92, 147-153. [CrossRef]

16. Tarakanov, I.; Yakovleva, O.; Konovalova, I.; Anisimov, A. Light-emitting diodes: On the way to combinatorial lighting technologies for basic research and crop production. Acta Hortic. 2012, 956, 171-178. [CrossRef]

17. Stutte, G.W.; Edney, S. Photoregulation of bioprotectant content of red leaf lettuce with light-emitting diodes. HortScience 2009, 44, 79-82. [CrossRef]

18. McCree, K.J. Action spectrum, absorptance and quantum yield of photosynthesis in crop plants. Agric. Meteorol. 1972, 9, 191-216. [CrossRef]

19. Apostol, K.G.; Dumroese, R.K.; Pinto, J.R.; Davis, A.S. Response of conifer species from three latitudinal populations to light spectra generated by light-emitting diodes and high-pressure sodium lamps. Can. J. Forest Res. 2015, 45, 1711-1719. [CrossRef]

20. Smirnakou, S.; Ouzounis, T.; Radoglou, K. Continuous spectrum LEDs promote seedling quality traits and performance of Quercus ithaburensis var. macrolepis. Front. Plant Sci. 2017, 8, 188. [CrossRef]

21. Darko, E.; Heydarizadeh, P.; Schoefs, B.; Sabzalian, M.R. Photosynthesis under artificial light: The shift in primary and secondary metabolism. Philos. Trans. R Soc. Lond. B Biol. Sci. 2014, 369, 20130243. [CrossRef]

22. Heuvelink, E.; Bakker, M.J.; Hogendonk, L.; Janse, J.; Kaarsemaker, R.; Maaswinkel, R. Horticultural lighting in the Netherlands: New developments. Acta Hortic. 2006, 711, 25-33. [CrossRef]

23. Bourget, C.M. An introduction to light-emitting diodes. HortScience 2008, 43, 1944-1946. [CrossRef]

24. Landis, T.D.; Pinto, J.R.; Dumroese, R.K. Light emitting diodes (LED): Applications in forest and native plant nurseries. For. Nurs. Notes 2013, 33, 5-13.

25. Bian, Z.H.; Yang, Q.C.; Liu, W.K. Effects of light quality on the accumulation of phytochemicals in vegetables produced in controlled environments: A review. J. Sci. Food Agric. 2015, 95, 869-877. [CrossRef]

26. Yeh, N.; Ding, T.J.; Yeh, P. Light-emitting diodes' light qualities and their corresponding scientific applications. Renew. Sustain. Energy Rev. 2015, 51, 55-61. [CrossRef]

27. Kozai, T.; Ohyama, K.; Chun, C. Commercialized closed systems with artificial lighting for plant production. Acta Hortic. 2006, 711, 61-70. [CrossRef]

28. Hodgson, E.; Lewys-James, A.; Rao Ravella, S.; Thomas-Jones, S.; Perkins, W.; Gallagher, J. Optimisation of slow-pyrolysis process conditions to maximise char yield and heavy metal adsorption of biochar produced from different feedstocks. Bioresour. Technol. 2016, 214, 574-581. [CrossRef]

29. Fang, G.; Zhu, C.; Dionysiou, D.D.; Gao, J.; Zhou, D. Mechanism of hydroxyl radical generation from biochar suspensions: Implications to diethyl phthalate degradation. Bioresour. Technol. 2015, 176, 210-217. [CrossRef]

30. Yan, J.; Han, L.; Gao, W.; Xue, S.; Chen, M. Biochar supported nanoscale zerovalent iron composite used as persulfate activator for removing trichloroethylene. Bioresour. Technol. 2015, 175, 269-274. [CrossRef]

31. Lehmann, J.; Kuzyakov, Y.; Pan, G.; Ok, Y.S. Biochars and the plant-soil interface. Plant Soil 2015, 395, 1-5. [CrossRef]

32. Atkinson, C.J.; Fitzgerald, J.D.; Hipps, N.A. Potential mechanisms for achieving agricultural benefits from biochar application to temperate soils: A review. Plant Soil 2010, 337, 1-18. [CrossRef]

33. Amendola, C.; Montagnoli, A.; Terzaghi, M.; Trupiano, D.; Oliva, F.; Baronti, S.; Miglietta, F.; Chiatante, D.; Scippa, G.S. Short-term effects of biochar on grapevine fine root dynamics and arbuscular mycorrhizae production. Agric. Ecosyst. Environ. 2017, 239, 236-245. [CrossRef]

34. Trupiano, D.; Cocozza, C.; Baronti, S.; Amendola, C.; Vaccari, F.P.; Lustrato, G.; Di Lonardo, S.; Fantasma, F.; Tognetti, R.; Scippa, G.S. The effects of biochar and its combination with compost on lettuce (Lactuca sativa L.) growth, soil properties, and soil microbial activity and abundance. J. Agric. 2017. [CrossRef]

35. Polzella, A.; De Zio, E.; Arena, S.; Scippa, G.S.; Scaloni, A.; Montagnoli, A.; Chiatante, D.; Trupiano, D. Toward an understanding of mechanisms regulating plant response o biochar application. Plant Biosyst. 2019, 153, 163-172. [CrossRef] 
36. Baronti, S.; Alberti, G.; Delle Vedove, G.; Di Gennaro, F.; Fellet, G.; Genesio, L.; Miglietta, F.; Peressotti, A.; Vaccari, F.P. The biochar option to improve plant yields: First results from some field and pot experiments in Italy. Ital. J. Agron. Riv. Agron. 2010, 5, 3-11. [CrossRef]

37. Hossain, M.K.; Strezov, V.; Chan, K.Y.; Nelson, P.F. Agronomic properties of wastewater sludge biochar and bioavailability of metals in production of cherry tomato (Lycopersicon esculentum). Chemosphere 2010, 78, 1167-1171. [CrossRef]

38. French, E.; Iyer-Pascuzzi, S. A role for the gibberellin pathway in biochar-mediated growth promotion. Sci. Rep. 2018, 8, 5389. [CrossRef]

39. Major, J.; Rondon, M.; Molina, D.; Riha, S.J.; Lehmann, J. Maize yield and nutrition during four years after biochar application to a Colombian savanna oxisol. Plant Soil 2010, 333, 117-128. [CrossRef]

40. Rondon, M.; Lehmann, J.; Ramírez, J.; Hurtado, M. Biological nitrogen fixation by common beans (Phaseolus vulgaris L.), increases with biochar additions. Biol. Fertil. Soils 2007, 43, 69-708. [CrossRef]

41. Asai, H.; Samson, B.K.; Stephan, H.M.; Songyikhangsuthor, K.; Homma, K.; Kiyono, Y.; Inoue, Y.; Shiraiwa, T.; Horie, T. Biochar amendment techniques for upland rice production in Northern Laos: 1. Soil physical properties, leaf SPAD and grain yield. Field Crops Res. 2009, 111, 81-84. [CrossRef]

42. Silber, A.; Levkovitch, I.; Graber, E.R. pH-dependent mineral release and surface properties of cornstraw biochar: Agronomic implications. Environ. Sci. Technol. 2010, 44, 9318-9323. [CrossRef] [PubMed]

43. Xiang, Y.; Deng, Q.; Duan, H.; Guo, Y. Effects of biochar application on root traits: A meta-analysis. GCB Bioenergy 2017, 9, 1563-1572. [CrossRef]

44. Prendergast-Miller, M.T.; Duvall, M.; Sohi, S.P. Biochar-root interactions are mediated by biochar nutrient content and impacts on soil nutrient availability. Eur. J. Soil Sci. 2014, 65, 173-185. [CrossRef]

45. Abiven, S.; Hund, A.; Martinsen, V.; Cornelissen, G. Biochar amendment increases maize root surface areas and branching: A shovelomics study in Zambia. Plant Soil 2015, 395, 45-55. [CrossRef]

46. Ding, Y.; Liu, Y.-X.; Wu, W.-X.; Shi, D.-Z.; Yang, M.; Zhong, Z.-K. Evaluation of biochar effects on nitrogen retention and leaching in multi-layered soil columns. Water Air Soil Pollut. 2010, 213, 47-55. [CrossRef]

47. D'Alessandro, D.M.; Smit, B.; Long, J.R. Carbon dioxide capture: Prospects for new materials. Angew. Chem. Int. 2010, 49, 6058-6082. [CrossRef] [PubMed]

48. Solomon, D.; Lehmann, J.; Thies, J.; Schafer, T.; Liang, B.Q.; Kinyangi, J.; Neves, E.; Petersen, J.; Luizao, F.; Skjemstad, J. Molecular signature and sources of biochemical recalcitrance of organic C in Amazonian Dark Earths. Geochim. Cosmochim. Acta 2007, 71, 2285e2298. [CrossRef]

49. Dumroese, R.K.; Pinto, J.R.; Heiskanen, J.; Tervahauta, A.; McBurney, K.G.; Page-Dumroese, D.S.; Englund, K. Biochar can be a suitable replacement for Sphagnum peat in nursery production of Pinus ponderosa seedlings. Forests 2018, 9, 232. [CrossRef]

50. Tilman, D.; Balzer, C.; Hill, J.; Befort, B.L. Global food demand and the sustainable intensification of agriculture. Proc. Natl. Acad. Sci. USA 2011, 108, 20260-20264. [CrossRef]

51. Sachs, J.; Remans, R.; Smukler, S.; Winowiecki, L.; Andelman, S.J.; Cassman, K.G.; Castle, D.; DeFries, R.; Denning, G.; Fanzo, J.; et al. Monitoring the world's agriculture. Nature 2010, 466, 558-560. [CrossRef]

52. Food and Agriculture Organization of the United Nations (FAO). The Future of Food and Agriculture-Trends and Challenges; FAO: Rome, Italy, 2017.

53. Mehlich, A. Use of triethanolamine acetate-barium hydroxide buffer for the determination of some base exchange properties and lime requirement of soil. Soil Sci. Soc. Am. Proc. 1938, 29, 374-378. [CrossRef]

54. Dumas, J.B.A. Procedes de l'analyse organic. Ann. Chim. Phys. 1831, 247, 198-213.

55. Black, C.A. Method of Soil Analysis, Part 2, Chemical and Microbiological Properties; American Society of Agronomy Inc.: Madison, WI, USA, 1965.

56. Liao, P.B.; Lin Kramer, S.S. Ion exchange systems for water recirculation. J. World Aquac. Soc. 1981, 12, 32-39. [CrossRef]

57. Bowman, R.A. A rapid method to determine total phosphorus in soils. Soil Sci Soc. Am. J. 1988, 52, $1301-1304$. [CrossRef]

58. Olsen, S.R.; Cole, C.V.; Watanabe, F.S.; Dean, L.A. Estimation of Available Phosphorus in Soils by Extraction with Sodium Bicarbonate; U.S. Department of Agriculture Circular No. 939; Banderis, A.D., Barter, D.H., Anderson, K., Eds.; U.S. Department of Agriculture: Asheville, NC, USA, 1954.

59. Rayment, G.E.; Higginson, F.R. Australian Laboratory Handbook of Soil and Water Chemical Method; Reed International Books Australia P/L; Inkata Press: Melbourne, Australia, 1992; p. 330. 
60. Conyers, M.K.; Davey, B.G. Observations on some routine methods for soil pH determination. Soil Sci. 1988, 145, 29-36. [CrossRef]

61. Rhoades, J.D. Salinity: Electrical conductivity and total dissolved solids. In Methods of Soil Analysis: Part 3 Chemical Methods; Sparks, D.L., Ed.; Soil Science Society of America: Madison WI, USA, 1996.

62. Greenberg, J.A.; Meyerhoff, M.E. Response properties, applications and limitations of carbonate-selective polymer membrane electrodes. Anal. Chem. Acta 1982, 141, 57-64. [CrossRef]

63. Maxwell, K.; Johnson, G.N. Chlorophyll fluorescence-A practical guide. J. Exp. Bot. 2000, 51, 659-668. [CrossRef]

64. Arnon, D.I. Copper enzymes in isolated chloroplasts. Polyphenoloxidase in beta vulgaris. Plant Physiol. 1949, 24, 1-15. [CrossRef]

65. Berihun, T.; Tolosa, S.; Tadele, M.; Kebede, F. Effect of biochar application on growth of garden pea (Pisum sativum L.) in acidic soils of Bule Woreda Gedeo zone southern Ethiopia. J. Argic. 2017, 2017, 6827323. [CrossRef]

66. Bünemann, E.K.; Bongiorno, G.; Bai, Z.; Creamer, R.E.; Deyn, G.D.; de Goede, R.; Fleskens, L.; Geissen, V.; Kuyper, T.W.; Mäder, P.; et al. Soil quality—A critical review. Soil Biol. Biochem. 2018, 120, 105-125. [CrossRef]

67. Eyles, A.; Bound, S.A.; Oliver, G.; Corkrey, R.; Hardie, M.; Green, S.; Close, D.C. Impact of biochar amendment on the growth, physiology and fruit of a young commercial apple orchard. Trees 2015, 29, 1817-1826. [CrossRef]

68. Olmo, M.; Villar, R. Changes in root traits explain the variability of biochar effects on fruit production in eight agronomic species. Org. Agric. 2019, 9, 139-153. [CrossRef]

69. Solaiman, Z.M.; Murphy, D.V.; Abbott, L.K. Biochars influence seed germination and early growth of seedlings. Plant Soil 2012, 353, 273-287. [CrossRef]

70. Viger, M.; Hancock, R.D.; Miglietta, F.; Taylor, G. More plant growth but less plant defence? First global gene expression data for plants grown in soil amended with biochar. GCB Bioenergy 2015, 7, 658-672. [CrossRef]

71. Mølmann, J.A.; Junttila, O.; Johnsen, O.; Olsen, J.E. Effects of red, far-red and blue light in maintaining growth in latitudinal populations of Norway spruce (Picea abies). Plant Cell Environ. 2006, 29, 16-72. [CrossRef]

72. Smirnakou, S.; Ouzounis, T.; Radoglou, K. Effects of continuous spectrum LEDs used in indoor cultivation of two coniferous species Pinus sylvestris L. and Abies borisii-regis Mattf. Scand. J. Forest Res. 2015, 32, 115-122. [CrossRef]

73. Casal, J.J. Shade avoidance. Arab. Book 2012, 10, e0157. [CrossRef]

74. Franklin, K.A.; Whitelam, G.C. Phytochromes and shade-avoidance responses in plants. Ann. Bot. 2005, 96, 169-175. [CrossRef]

75. Pedmale, U.V.; Huang, S.C.; Zander, M.; Cole, B.J.; Hetzel, J.; Ljung, K.; Reis, P.A.B.; Sridevi, P.; Nito, K.; Nery, J.R.; et al. Cryptochromes interact directly with PIFs to control plant growth in limiting blue light. Cell 2016, 164, 23-245. [CrossRef]

76. Montagnoli, A.; Terzaghi, M.; Di Iorio, A.; Scippa, G.S.; Chiatante, D. Fine- root morphological and growth traits in a Turkey oak stand in relation to seasonal changes in soil moisture in the southern Apennines, Italy. Ecol. Res. 2012, 27, 725-733. [CrossRef]

77. Montagnoli, A.; Di Iorio, A.; Terzaghi, M.; Trupiano, D.; Scippa, G.S.; Chiatante, D. Influence of soil temperature and water content on fine root seasonal growth of European beech natural forest in southern Alps, Italy. Eur. J. For. Res. 2014, 133, 957-968. [CrossRef]

78. Montagnoli, A.; Dumroese, R.K.; Terzaghi, M.; Onelli, E.; Scippa, G.S.; Chiatante, D. Seasonality of fine root dynamics and activity of root and shoot vascular cambium in a Quercus ilex L. forest (Italy). Forest Ecol. Manag. 2019, 431, 26-34. [CrossRef]

79. Brennan, A.; Jiménez, E.M.; Puschenreiter, M.; Alburquerque, J.A.; Switzer, C. Effects of biochar amendment on root traits and contaminant availability of maize plants in a copper and arsenic impacted soil. Plant Soil 2014, 379, 351-360. [CrossRef]

80. Sun, Q.; Yoda, K.; Suzuki, M.; Suzuki, H. Vascular tissue in the stem and roots of woody plants can conduct light. J. Exp. Bot. 2003, 54, 1627-1635. [CrossRef]

81. Sun, Q.; Yoda, K.; Suzuki, H. Internal axial light conduction in the stems and roots of herbaceous plants. J. Exp. Bot. 2005, 56, 191-203. [CrossRef]

82. Kasperbauer, M.; Hunt, P. Biological and photometric measurement of light transmission through soils of various colors. Bot. Gaz. 1988, 149, 361-364. [CrossRef] 
83. Tester, M.; Morris, C. The penetration of light through soil. Plant Cell Environ. 1987, 10, 281-286. [CrossRef]

84. Li, C.; Liu, D.; Li, L.; Hu, S.; Xu, Z.; Tang, C. Effects of light-emitting diodes on the growth of peanut plants. Agron. J. 2018, 110, 2369-2377. [CrossRef]

85. Rabara, R.C.; Behrman, G.; Timbol, T.; Rushton, P. Effect of spectral quality of monochromatic LED lights on the growth of artichoke seedlings. Front. Plant Sci. 2017, 8, 190. [CrossRef]

86. Wang, Y.; Pan, F.; Wang, G.; Zhang, G.; Wang, Y.; Chen, X.; Mao, Z. Effects of biochar on photosynthesis and antioxidative system of Malus hupehensis Rehd. seedlings under replant conditions. Sci. Hortic. 2014, 175, 9-15. [CrossRef]

87. Montagnoli, A.; Terzaghi, M.; Fulgaro, N.; Stoew, B.; Wipenmyr, J.; Ilver, D.; Rusu, C.; Scippa, G.S.; Chiatante, D. Non-destructive phenotypic analysis of early stage tree seedling growth using an automated stereovision imaging method. Front. Plant Sci. 2016, 7, 1644. [CrossRef] [PubMed]

88. Murchie, E.H.; Lawson, T. Chlorophyll fluorescence analysis: A guide to good practice and understanding some new applications. J. Exp. Bot. 2013, 64, 3983-3998. [CrossRef] [PubMed]

89. Ritchie, G.A. Chlorophyll fluorescence: What is it and what do the numbers mean? In USDA Forest Service Proceedings; RMRS-P-43; USDA Forest Service: Denver, CO, USA, 2006.

90. Schansker, G.; Tóth, S.Z.; Holzwarth, A.R.; Garab, G. Chlorophyll a fluorescence: Beyond the limits of the QA model. Photosynth. Res. 2014, 120, 43-58. [CrossRef] [PubMed]

91. Huang, Z.A.; Jiang, D.A.; Yang, Y.; Sun, J.W.; Jin, S.H. Effects of nitrogen deficiency on gas exchange, chlorophyll fluorescence, and antioxidant enzymes in leaves of rice plants. Photosynthetica 2004, 42, 357-364. [CrossRef]

92. Salisbury, F.J.; Hall, A.; Grierson, C.S.; Halliday, K.J. Phytochrome coordinates Arabidopsis shoot and root development. Plant J. 2007, 50, 429-438. [CrossRef] [PubMed]

93. Akhtar, S.S.; Andersen, M.N.; Liu, F. Residual effects of biochar on improving growth, physiology and yield of wheat under salt stress. Agric. Water Manag. 2015, 158, 61-68. [CrossRef]

94. Yeboah, S.; Zhang, R.; Cai, L.; Li, L.; Xie, J.; Luo, Z.; Wu, J.; Antille, D.L. Soil water content and photosynthetic capacity of spring wheat as affected by soil application of nitrogen-enriched biochar in a semiarid environment. Photosynthetica 2017, 55, 532-542. [CrossRef]

95. Abel, S.; Peters, A.; Trinks, S.; Schonsky, H.; Facklam, M.; Wessolek, G. Impact of biochar and hydrochar addition on water retention and water repellency of sandy soil. Geoderma 2013, 202-203, 183-191. [CrossRef]

96. Paneque, M.; De la Rosa, J.; Franco-Navarro, J.D.; Colmenero-Flores, J.M.; Knicker, H. Effect of biochar amendment on morphology, productivity and water relations of sunflower plants under non-irrigation conditions. Catena 2016, 147, 208-287. [CrossRef]

97. Shimazaki, K.I.; Dio, M.; Assmann, S.M.; Kinoshita, T. Light regulation of stomatal movement. Annu. Rev. Plant Biol. 2007, 58, 219-247. [CrossRef]

98. Jensen, N.B.; Clausen, M.R.; Kjaer, K.H. Spectral quality of supplemental LED grow light permanently alters stomatal functioning and chilling tolerance in basil (Ocimum basilicum L.). Sci. Hortic. 2018, 227, $38-47$. [CrossRef]

99. Son, G.H.; Wan, J.; Kim, H.J.; Nguyen, X.C.; Chung, W.-S.; Hong, J.C.; Stacey, G. Ethylene-responsive element-binding factor 5, ERF5, is involved in chitin-induced innate immunity response. Mol. Plant Microbe Interact. 2012, 25, 48-60. [CrossRef] [PubMed]

100. Kim, S.J.; Hahn, E.J.; Heo, J.W.; Paek, K.Y. Effects of LEDs on net photosynthetic rate, growth and leaf stomata of chrysanthemum plantlets in vitro. Sci. Hortic. 2004, 101, 143-151. [CrossRef]

(C) 2020 by the authors. Licensee MDPI, Basel, Switzerland. This article is an open access article distributed under the terms and conditions of the Creative Commons Attribution (CC BY) license (http://creativecommons.org/licenses/by/4.0/). 